Item, si durante la dite true nule persone, de quelle condicion qelle soit, face guerre a nul des Rois, que lautre neidera en fet, nen consail a lui, ne lui rescettera ne nul de sa partie, dedenz son poer enguerrant lautre.

Item quelle houre, que le Roi Descoce voudra envoier outre mer, dedenz la dite true, ses messages, de quelles condicions quils soient, prelatz ou autres, qil le puise faire, come en tenps de pais, par terre, e par mer, sanz nul manere denpechement.

Item si nul des Rois voule enveer messages a lautre, qil veignent primerement as Gardeins de la true, e monstrent a eux qil soient messages, e soient resceu covenablement, de passer come en tenps de pais.

Item que la dite true en toutes les condicions avantdites soit acorde, et afferme, par lettres et serementz, des almes les Rois, de Prelatz, Countes, et barons des Realmes, et auxi *conferme* par nostre Seint Pier le Pape, e tesmoignez par le Roi de Fraunce, comme medne ami.

* This clause is inserted above the line.

\title{
Thomas Harding
}

Amonast the English refugees who, in the first years of Elizabeth's reign, found shelter from the rising storm of persecution in the Studium Generale of Louvain, was the Oxford professor Thomas Harding. ${ }^{1}$ He had not always been a decided Roman catholic. In Wykeham's College at Winchester, where he was prepared for the university, ${ }^{8}$ he possessed some of the writings of the reformers and recommended them to his fellow students. ${ }^{3}$ According to Strype, it was on account of his protestant zeal that, through the intervention of Edward VI, he was elected warden of New College, Oxford, where he had been successively student, probationer, and fellow, and, in 1542, had been appointed the King's Professor of Hebrew. ${ }^{4}$ On Mary's accession, however, he subscribed the required declaration, evidently from a deeper motive than the fear of offending the susceptibility of those in power. It is not a mere coincidence that at that time several men were studying in New College who were to be amongst the most learned of the

1 Born at Backington, Somerset., 1518 : Oxonienses (London, 1681), i. 138. The dates of degrees taken by persons mentioned in this article are taken throughout from Wood.

- After having for some time attended the Barnstaple Grammar Sohool: Dugdale and Burnett, Curiasities of Great Britain (1840), p. 96. He was admitted in 1628 to Winchester: Wykeham and his Colleges (1852), p. 397.

- For his lending Frythe's Purgatory (1532) to John For see 'Reminiscences of John Lauthe' in Nichols, Narratives of the Days of the Reformation, Camden Society (1859), pp. 55, 56.

- He was elected fellow of New College in 1536 and became a bachelor of arts on 28 February 1537; master of arts on 15 March 1542. He delivered on 22 July 1547 an 'eloquent oration' on the solemn entrance of Richard Coxe as chancellor into Oxford (Wood, i. 689, 694, and 700). 
Romanists under Maryand Elizabeth. ${ }^{1}$ Moreover, Harding was just then engaged in theological studies ; in July 1552 he was admitted to the degree of bachelor, ${ }^{2}$ and two years later, on 13 July 1554, to that of doctor of divinity. ${ }^{3}$ This may account for his change in religious belief, which did not pass unnoticed. It is recorded that Lady Jane Grey, whose education had been entrusted partly to him, wrote from her prison to upbraid him. ${ }^{4}$ He must have come to the notice of the Lord Chancellor, Bishop Gardiner, who attached him to his service as chaplain, bestowed on him a prebend in his cathedral of Winchester, and appointed him, on $17 \mathrm{July} \mathrm{1555,}$ treasurer of the church of Salisbury. Besides these ecclesiastical preferments, Gardiner gave him personal esteem and intimate friendship, and chose him for one of the executors of his will. ${ }^{5}$

At the accession of Elizabeth, refusing to recognize the queen's spiritual supremacy, he forfeited his office and benefice : as early as January 1559 Thomas Lancaster was appointed in his place as treasurer of Salisbury. 6 The new settlement of the church, which was practically forced on England and her parliament in the first months of Elizabeth's reign, and the conduct of religious affairs by Cecil and Bacon, made life almost impossible to men like Harding, who under Mary's reign had devoted their best efforts to a counter-reformation, and had tried to rouse the mass of the people from the indifference to dogmatic questions into which they had been awed by the despotic Henry VIII or the ministers of Edward VI. He came over to the Spanish Netherlands with several other Oxford and Cambridge scholars, and was mentioned as residing in Flanders in May 1561 by Dr. Saunders in his Report to Cardinal Moroni.? It is not known where he spent the first years of his exile; but he soon settled for good in Louvain, which in the sixties of that century had become the catholic Oxford, whence proceeded all the assaults on the newly constituted Anglican

1. There were John Borall, a future dean of Winchester, who became a master of arts in 1548; Nicolas Saunders, bachelor of civil law in 1551; John Harpesfield, bechelor of divinity in 1551; John Rastell, bachelor of arts in 1552; Griffith Williams, bechelor of laws in 1552; Nicolas Harpesfield, doctor of civil law in 1553; John Martiall, bachelor of civil law in 1550; Thomes Stapleton, bachelor of art in 1556; John Fowler, John Hannington, and John Plankeney, bachelors of arts in 1556; Owen Lewis, bechelor of civil law in 1568.

Wood, i. 706.

2 Ibid. p. 710.

- After 1542 Harding is recorded to have been chaplain to the household of Henry Grey, marquis of Dorchester, afterwards duke of Suffolk, the great patron of protestants. Jane's letters to Harding and to her sister were sent to Bullinger (Zurich Lethers (Parker Society Publications), iii. 1847, 304, 306).

- 'Mr. Harding my Chaplayn': will of Stephen Gardiner, bishop of Winchester, 1555, in Nichols and Bruce, Wills from Doctors' Commons; Wills of Eminent Persons, 1495-1695, Camden Soc. (1863), p. 46.

- Wood, i. 138.

'P. Guilday, 'The English Catholic Refugees at Louvain 1558-75', in Melanges Charkes Moeller (Louvain, 1914), ii. 179. 
church, and even, according to the reports of the spies, all the plots against its temporal head. ${ }^{1}$ He was matriculated as member of the university on 7 May $1563,{ }^{2}$ and lived in rooms in the parish of St. Gertrude. ${ }^{3}$

From Louvain he attacked Bishop Jewel's Apologia Ecclesiae Anglicanae of 1562, and published at Antwerp in 1563 his Confutation of a Book called An Apologie of the Church of England." In the following year, 1564, he accepted the famous challenge made by Jewel in his sermon preached at St. Paud's Cross on the second Sunday before Easter $1560,{ }^{5}$ and published $A n$ Answere to Maister Juelles Challenge. He thus levelled the first blows of the famous controversy in which the refugees of Lrouvain brilliantly defended their views. That these and similar pamphlets struck home appears from their having led to 'a severe proclamation that no such book written in English by the Catholick party should be received or read in England under great punishments ' ${ }^{8}$ The impression made by Harding's work in particular can be gauged from several passages in the sermons of the Anglican bishops ${ }^{7}$ and in the correspondence of the reformers, as well as in that between Philip II and his ambassador in England. ${ }^{8}$ As was to be expected, Jewel published $A$ Defence of the Apologie of the Church of England (1564), and attacked his opponent in subsequent pamphlets and in the pulpit, which occasioned the publishing of several replies by Harding : $A$ Detection of Sundry Errors, Slanders, dec., in Jewell's Defence of the Apologie, Louvain, 1564; Answer touchyng certaine Untruths which Mr. John Jewell charged him with in his late Sermon at Paul's Cross, July 8, 1565, Antwerp, 1565 (in 8vo and in 4to); Rejoynder to Mr. Jewell's Reply concerning the Challenge and the Private Mass, Antwerp, 1566 (in 4to) ; A Second Rejoynder to

1 Ibid. p. 181 ; Cambridge Modern History, ii. 386. The great number of Engliah divines at work in Louvain must have given the more annoyance, as in the beginning of Elizabeth's reign there were hardly any students in theology in Oxford and none capable of being appointed lecturers (Wood, i. 717, 718).

- Liber Quartus Intitulatorum in Univ. Lovan. 1528-68, fo. 391 (Archives du Royaume, Bruxelles, Fonds Univ. de Louvain, no. 42).

- He was not at all attached to this parish, as is implied in the article in the $D^{\prime}$ ch. of Nat. Biogr.

- Iovanii, typis Jois Boegarts, in 4to; it was reprinted at Antwerp 1565, in 4to (Wood, i. 139).

- Ibid. pp. 132 ff.

- Persons, A Relation of a Trial made before the King of France, an. 1600, between the Bishop of Evreux and the Lord Plessis Mornay (1604), pp. 33 ff., quoted by Wood.

- Compare passages mentioned in the General Index to the Publications of the Parker Society, Cambridge, 1855, s.v.

- Compare letter of Jewel to H. Bullinger and In Lavater, 8 February 1568, in the Zurich Letters, i. 1842, 146-50 ; letters of Guzman de Silva to Philip II, London, 14 and 21 April 1565; Philip's answer, 6 June 1565, in Calendar of Lellers and State Papers of the Reign of Elizabeth, preserved in the Archives of Simancas, edited by M. A. 8 Hume, i. 418, 419, 432. 
Mr. Jewell's Reply against the Sacrifice of the Mass, Louvain, 1567 (in 4to).

The history of this controversy has not yet been written ; ${ }^{1}$ indeed, it cannot be written until there exists a corpus of catholic divines, like that of the protestant reformers published by the Parker Society. These authors did not enjoy in their exile either the advantages of peace and financial prosperity or any official sanction. Their books were systematically suppressed in England and attracted little attention in the foreign countries where they were published. The language in which they were written must have been one cause of that indifference. It was probably to rouse the interest of the divines of the Continent that William Rainolds, a fellow countryman, rendered Harding's works into Latin. ${ }^{2}$ Indigence prevented the printing of this translation, and probably also of some works of Harding himself, such as his $H$ istoria Divortii, a history of Henry VIII's separation from Rome. ${ }^{3}$

This lack of sound material renders an adequate estimate of the value and influence of Harding's writings impossible, but it may be safely said that in the struggle against the Anglican church he was one of the most powerful and expert protagonists of the Roman orthodoxy. He was one of the most influential members of the English community at Louvain, and possibly lectured in the Oxford Study House, which the refugees had opened for the benefit of the exiled students." As the records of the faculty of divinity of that period have perished, no details can be supplied; yet the fact that Valerius Andreas inserted him in the list of Doctores S. Theologiae ac Professores qui titulum aliunde Lovanium attulerunt, on a line with Richard Smith, implies that if he was not an actual professor either of Hebrew or of theology, he was honoured as such, and was at least a member of the faculty of theology. ${ }^{5}$ He took an active interest in the

1 See Frere, The English Church in the Reign of Elizabeth and James I (1904), i. $80-92$.

- William Rainolds or Reginald, alias Rossaeus, was a native of Pinhoe, Devonshire, who abjured heresy in Rome and became professor of Scripture and Hebrew at Rheims. He was famous as poet, rhetorician, musician, mathematician, historian, philosopher, and divine, and wrote several polemical tracte. He died as rector of the Beguinage of Antwerp, and was baried in the church of that community (Paquot, Frati Doctorales Facultatia Theologiae Lovaniensis, Brussels, Royal Library MS. 17567, p. 30 ; Dict. of Nat. Biogr.).

- The manuscript, which has disappeared, was attributed to Harding by Jaachim Lo Grand, Préfet de la Bibliothèque Royale de France, in his reply to Burnet (Histoire du Divorce (Paris, 1688), ii. 47 ff. ; Pequot, Fasti, p. 30).

- 'Nicolas Senderus, Ioan. Martial, et Thomas Stapleton, Angli, conducunt aimul domum in Nova Platea a Ioanne a Schore ad triennium, Lovanii, 28 iulii, 1585, coram Wamel, in Actis ' (Bax, Historia Universitatis Lovàniensis, Brussels, Royal Library MS. 22172, ii. 149).

- Valerius Andreas, Fasti Academici Studii Generalis Lounniensis (Louvain, 1650), p. 85 . 
studies of his young countrymen, occasionally taking the matriculation oath for such as were not yet of age. ${ }^{1}$ He gave much help to William Allen in the foundation of the English college at Douai. ${ }^{2}$ He did not, however, himself join the young body, but remained in the old university town, a providence for his needful countrymen and a great promoter of Greek and Hebrew learning and of solid theology, both by his advice and his untiring exsmple, until in 1572 an illness overtook him. He felt death drawing near, and on 7 September made his will in presence of three friends, William Tailor, Nicolas Fox, and John Martial. Nine days later, on 16 September, he died.

The account of his executors, which according to the academic rules had to be delivered before the rector, with a copy of the will in English and a Latin translation annexed, is still extant amongst the documents relative to the university of Louvain in the Records of the Realm at Brussels, where I found it after centuries of oblivion. ${ }^{3}$ This document gives many interesting particulars of the life and conditions of the members of the English colony in Louvain and of English refugees of that period in general. It shows that his friends were deeply affected by the death of Harding: his likeness was taken from the corpse before it was embalmed and laid to rest in the church of St. Gertrude. The university was formally invited by the beadle of the faculty of theology to the solemn funeral service in the same church. ${ }^{4}$ According to the desire of the deceased another service, and later on, a trigenarium and an anniversary, were celebrated in the Syon convent at Mishagen, near Antwerp, which were attended by the executors and several of the Louvain friends. ${ }^{5}$ The executors appointed by Harding were two of his intimate

1 Lib. iv Intit., I8-19 May 1568 ' gwilhelmus phelps anglus pauper in theologia: (in margin :) iuravit pro eo D. Doctor Hardingus' (fo. 443).

Paquot, Fasti, p. 29.

- The account of the execution takes up seventeen folio pages (pp. 1 to 21); the copy of the original testament in English follows (pp. 23 to 26), with a Latin translation of it by John Pulley, Doctor Utriusque Inris (pp. 27 to 29). This John Pulley is probably identical with 'John Poullye' who is mentioned in Stephen Gardiner's will as belonging to his household (Niohols and Brace, p. 46).

- This detail corroborates the supposition that Harding was an actual member of that faculty.

- The account notes down the expenditare of 12 flor. $13 \frac{1}{2}$ st. for the services celebrated 'apud moniales Anglices in monesterio inxte Antuerpiam ', es well as for the journey. A sum of 8 flor. is put down for a 'prandium seu refectio' in the same convent on that occasion. Another entry notifies "pro expensis factis in profectione nostra ad anniversarium eius in Syon 4 flor. 3 st.' It is clear from the account that, if not in September 1573, at least in September 1572 the Bridgetines were still at Mishagen and had not left yet for Mechlin, as R. Lechat (Une Communauté Anglaise refugise a Malines in Annales du Congres Historique et Arehélogique de Malines (Malines, 1911), ii. 243-59) and P. Guilday (The English Catholic Colleges and Convents in the Catholic Low Countries (Louvain. 1914), p. 58) soem to imply. 
friends : the first, Thomas Hyde, who had probably been his pupil at Now College, and, later, prebendary and head master of Winchester, became afterwards one of the most celebrated professors of Douai ; ${ }^{1}$ the second was Thomas Bayley, an English priest, formerly a student of divinity in Cambridge. ${ }^{2}$ They took in hand the management of the inheritance; they made an inventory of the money and a few jewels, chiefly rings, representing a value of about 850 florins. From an entry in the list of precious objects, Conspicillia, and this other, Item cocleare argenteum cum uasculo argenteo pro oculis abluendis, it appears that Harding's eyes and sight were delicate. The other goods consisted chiefly of gowns and dresses which, to judge from the materials, 'ustade, halfe-sette, grouegreine', and from the description, had been brought over from England.

The scholar is revealed by the reams of paper and the leaden or leathern writing instruments. More characteristic even is the fine collection of books which was sold by auction like the rest of the goods. The list shows that Harding was interested in Italian literature : he possessed a Petrarch, a translation of Ptolemy's letters in that language, and a work by Blondus. He had not interrupted his study of Hebrew : besides the lexicons of Pagnini, Munster, and Kimchius, he owned the grammatical treatises of two Louvain hebraists, Campensis and Clenardus. With the latter he seems to have had a common interest in travels, in foreign peoples and languages, for the famous Epistolae Peregrinationum of the Diest scho'ar is mentioned next to some collections of letters from India. The greater part of the books, however, are works of divinity and controversy: besides the writings of the fathers of the church and of the schoolmen, the list contains the works of More and Fisher, a life of Reginald Pole, Cooper's Thesaurus, Florence Volusene's De Animi Tranquillitate, and In Psalmum XV Commentatio. Further, the apologetic writings of his friends : Alan Cope's Dialogues, Saunders's Monarchia and Orations, his De Officio Missae and De Adoratione Imaginum, Richard Smith's works, his own Rejoynder against Jewell, and many more. Nearly as numerous as the works of his countrymen are those of the Louvain professors of divinity: the controversial writings of Ruard Tapper and Michael de Bay, Pighius's Hierarchia, Hessels's Eucharistia, and Sonnius's Demonstrationes Religionis Christianae $e$ Verbo Dei ; similarly the exegetic treatises of Jansenius on the

1 Thomes Hyde was matriculated at Louvain on 5 April 1563: 'D. Thomas Hyde nuberiensis [of Newbury] anglus' (Lib. iv Intit., fo. 390; seo Wood, i. 250 699, 703, and Dict. of Nat. Biogr.).

3 Thomas Bayley was matriculated at Louvain on 31 July 1563 : 'Thomas baleus, baccalaureus formatus Cantabrigiao-paper [i.e. he did not pay the full matriculation fees]-preebyter anglus' (Lib. iv Intit, fo. 393). 
psalms, of Sasbout on the epistles of St. Paul and on Isaiah, of Titelmans on the canticles and the psalms, Lindanus's Panoplia Evangelica and the De optimo Genere Interpretandi Scripturas by the same author. The presence of these and many more of the works of these professors in Harding's collection, as well as in that of John Ramridge, ${ }^{1}$ makes it almost certain that the Louvain faculty of theology exercised a great influence on the English apologetic school.

Harding's will testifies to his generous charity towards his poorer countrymen, who from a state of relative prosperity in England, had fallen to the depths of want in their exile. First amongst these ranked the sisters of Syon House at Mishagen, to whom he bequeathed a sum of 240 florins. ${ }^{2}$ A special legacy of 24 florins was left to their abbess, Lady Catherine Palmer; the small sum of $3 \frac{1}{2}$ florins was given to two of the members, Doctor Saunders's sister, Margaret, and Sister Bridget. ${ }^{3}$ A legacy of 6 florins was bequeathed to the Charterhouse at Bruges, ${ }^{4}$ and to the Dartford community near the same town ${ }^{s}$ further, in Louvain, to the two communities which had taken up English refugees, the Minorites and the Poor Clares, as well as to the Austin canonesses at St. Ursula's. In the latter convent a special bequest of 4 thalers ( 4 flor. and 16 st.) was made to Sister Elizabeth Woodford, who was the link between the suppressed abbey at Burnham and the developing community in Louvain, as also to the two daughters of the venerable and generous man who had sheltered her in her native country and accompanied her into exile, the Sisters Margaret and Dorothy Clement. ${ }^{6}$ Harding stipulated that 6 stivers should be offered to every English

1 This doctor of divinity of Oxford, who was dean of Lichfield in Mary's reign, went to live in Louvain in 1564 and was killed in 1568.

- Hamilton, The Angel of Syon, including R. Parsons's History of the Wanderings of Syon (1905), pp. 104 ff. This community was generally helped by the generosity of other exiles. So Foley, Records of the English Province of the Society of Jesw, vol. vii (1883), pt. i, p. 350 .

- This Sister Bridget probably succeoded to Catherine Palmer as abbess ; Bridgwater (Concertatio Ecclesize Catholicase in Anglia, Trier, 1583) mentions her in his inder: 'Domine Brigitte Abbatisea Monialium D. Brigittae cum viginti lectissimis ac nobilibus virginibus Anglis in exilio servit Deo in magna paupertate \& reram omnium penuria.'

- See Hendriks, The London Charterhouse: its Monks and ito Martyrs (1889); Guilday, English Catholic Colleges and Convents, pp. 41'ff.; Lochat, Les Refugies Anglais aux Pays-Bas 1558-1603 (Louvain, 1914), pp. 27 ff.

- Guilday, p. 414.

- Guilday, p. 378. 'Magister Dootor Ioannes nobilis Anglus' was matriculated in the Louvain Univengity with his gon Thomas on 27 March 1562 (Lib. iv Intit., fo. 579). Dorothy Clement was a professed nun in the convent of the Poor Clares; seo Sanderus, De Visibili Monarchia Ecclesiae, Louvain, 1571, pp. 710-12; W. Bang, Acta Anglo-Lovaniensia in Englische Studien (Leiprig, 1908), p. 246. The Lifo of Mother Margaret Clement, by Sister Elizabeth Shirley, is preserved in manuscript at St. Augustine's Priory, Newton Abbot. 
priest abiding in the Low Countries, and according to the account there were sixty-one who benefited by this bequest. Further, some assistance was given to those who in these days of bewilderment favoured the cause of the English catholics with more or less conviction and constancy, and who often wanted pecuniary help themselves : to the fickle Sir Thomas Copley, ${ }^{1}$ who at that time was in sore trouble, a sum of 24 florins ; to Sir John Gage, ${ }^{2}$ $10 \frac{1}{2}$ florins. They evidently were on familiar terms with the deceased, for he left to their respective wives all his 'Roman silken pictures'.

A lady, Elizabeth Covell, who received 20 florins, was another acquaintance, for in the account a Henry Covell is mentioned as having borrowed a sum of 80 florins. Harding remembered in his will his intimate friend, the noble-hearted Francis Englefield, ${ }^{8}$ whom Queen Elizabeth called an obstinate rebel, and whom Saunders praised as the greatest of his countrymen. They probably had become acquainted in the household of Bishop Gardiner, who had chosen them as executors of his will." Harding requested that 'three sargeant rings of gold having the inscription: Lex arma Regum', which had belonged to his former lord, should be given to Englefield, who was furthermore reminded that Mr. Twattes, another of Gardiner's executors, ${ }^{6}$ had still one of his rings for which he ought to answer. To enother friend, Mr. Shelton, a sum of 180 florins was left, as well as a golden ring with a sapphire. To Mr. John Culme was offered a legacy of 60 florins, with the request that he should pray for the repose of the soul of Bishop Gardiner. There are also some smaller legacies to friends, who evidently did not belong to the social rank of a Gage or an Englefield. A new gown was left to Mr. Bavand, perhaps identical with the John Bavant of Christ Church, Oxford, who became master of arts in 1552 ; a gold coin was to be given to a Mr. Dominick and to Mr. Wilson, about whom no other details are recorded, as well as to Richard Smith, a priest, who can hardly be identified; ${ }^{\circ}$ further to Nicholas Fox and

3 Dict. of Nat. Biogr.; Wood, i. 133 ; Loohat, pp. 62, 81 ff.

- Constable of the Tower and Iord chsmberlain in Mary's reign (J. M. Stone, The History of Mary Queen' of England, London, 1901, pp. 234, 305). The daughter of a Mrs. Gage entered the convent of the English Benedictines of Brugsels in 1807 (Guilday, p. $258 \mathrm{n}$.).

- 'D. Franciscus Englefildius miles Anglus' was matriculated in Louvain University in January 1663 (Lib. iv Intit., fo. 386; tives of the Days of the Reformation, p. 95 ; Lochat, pp. 45-6).

- Cp. J. G. Nichols and J. Bruce, Wills from Doctors' Commons, p. 46.

- Thomas Thraites, as he is called in Gardiner's will (Nichols and Bruce, p. 46), soems to have belonged to the chancellor's household.

- In the Lib. iv. Intit. of Louvain Univeraity the name Riahard Smith was entered three times from 1560 to 1569 . One is the famous Oxford professor of divivity, who 
Thomas Freeman, whose names occur on the matriculation lists of the university and on other documents of that period. ${ }^{1}$ Finally Harding bestowed some gifts, probably as mere keepsakes, on some of his Louvain friends, who were amongst the most conspicuous of his countrymen. A sealing ring with a red stone was bequeathed to Dr. Owen Lewis, the future bishop of Cassano ; ${ }^{8}$ a gold coin to the protagonist of the Louvain apologetic school, Dr. Nicolas Saunders; ${ }^{3}$ to Alan Cope,' 'The Lovanyone Luske', es John Foxe called him, ${ }^{5}$ euthor of the Syntaxis Historiae Evangelicae, 1572, who later on became a canon in Rome; to John Fenn, formerly the head master of St. Edmundsbury, probably at that time already chaplain of the English convent of St. Ursula in the university town, which flourished under his able direction ; ${ }^{6}$ to William Knot, doctor of laws, ${ }^{7}$ and to the former usher of Winchester School, John Martial, afterwards of the newly-founded college of Douai. ${ }^{8}$

taught in Louvain in Edward's reign : 'M. noster Richardus Smythous, reintitulatus' 15 February 1581 (fo. 367). This entry seems to be in opposition with Wood's statement about Richard Smith's whereabouts in the beginning of Elizabeth's reign (Athen. Oxon. i. 110 ff., 689 ; Lovaniensis (Louvain, 1650), p. 85; Dict. of Nat. Biogr.). The other two entries are: 4 April 1560, 'Richarde Smytho anglus' (fo. 360), and 4 May 1563, 'M. Richardus Smytheus, lincolniensis anglus, gratis quia pauper' (fo. 391).

1 Nioholas Foxe was matriculated in Louvain on 25 June 1568, 'D. Nicolaus Forus, Anglus'; Freeman in December 1562, 'Thomas Fremannus anglus' (Liber iv Intit, resp. ff. 386 and 426). The latter is perheps identical with Thomas Freeman who was master of St. Paul's School from 1549 to 1559 (Wood, i. 11). They are mentioned amongst the friends of Ramridge in the account of his executors, as well as in the list of the refugees who received part of the subeidy eent by Pope Gregory XIII : Domino Thoma Fremano sc. 20; Nicolao Foxo sc. 5 (Guilday, English Catholic Refugees, ii. 187).

Owen Lewir had been fellow of New College since 1533 and took the degree of civil law on 21 February 1559. He did not go straight from England to Dousi, as appears from the Lib. iv Intit. of Louvain University (fo. 390), in which his name was entered on 5 April 1563 : 'Adoynus Lodoicus Wallus anglue.' He probsbly took the degree of doctor in Louvain before he was appointed professor at Douai. He was one of the most conspicuous catholics, since in 1587 he was William Allen's competitor for the see of Mechlin. See Thomar Knox, Cardinal Alten's Letters and Memoriats, 1532-94 (1878-82), p. 322 ; Leohat, pp. 34, 160 ff., 177 ff. ; Dict. of Nat. Biogr.

- Nicolas Sanders, formerly fellow of New College, was matriculated in the Louvain University on 12 November 1564: 'D. M. N. Nicolaus Sandrus Bacre theologie doctor' (Lib. iv Intit., fo. 410; Wood, i. 162 ff. ; Dict. of Nat. Biogr.).

- Alan Cope, fellow of Magdalen College, doctor of Oxford University in 1558, was matriculated at Louvain on $4 \mathrm{May} 1563$ : 'M. Alanus Copus Londiniensis art. mag. ; anglus; gratis quis panper' (Lib. iv Intit., fo. 391 ; Wood, i. 157, 715; Dict. of Nat. Biogr.).

- J. G. Nichols, Narratives of the Days of the Reformation, pp. 16, 59.

- John Fenn, formerty fellow of New College, was matriculated at Louvain on 29 March 1564 : 'Ioannes Fen anglus pauper' (Liber iv Intit., fo. 403; Wood, i. 320; Guildey, p. 379).

' He was matriculated in Louvain on 8 April 1569: 'Guilhelmus Knot Anglus V.I. Doctor' (Liber iv Intit., fo: 451).

- John Martial, another old fellowiof New College, was matriculated in the Louvain

VOL. XXXV.-NO. OXXXVIII. 
All these men were devoting their abilities to the same object that Harding had followed in the studies and activities of his last years, the struggle against the current of ideas that had estranged them from their home. Though life had become unbearable or dangerous in England, the affection for their native country was as fresh with them, and especially with Harding, as in the days when he was celebrated for his learning and favoured by king and court. Indeed he bequeathed a sum of 10 pounds sterling to New College, where he had spent so many days of his life, where he had gone through all the stages from freshman to warden, and where he had found the greater number of his friends who were staunch to him in exile as in prosperity. This legacy was made without the stipulation added by other donors, that their bequests to English institutions should be dependent on the re-establishment of the Roman hierarchy. Harding left important sums of money to his servant, William Smyth, ${ }^{1}$ on condition that he should place himself at the disposal of the executors to see that his bequests were performed in England, amongst which the legacy to New College was mentioned in particular. ${ }^{3}$ It was not possible for Hyde or for Bayley to venture into England, although a great part of the inheritance had remained in Wiltshire or in Winchester. Some goods and money had been entrusted to a Mr. Richard Pickering and his wife Cecile; they were left to them by the will, with the stipulation that some of the silver should be reserved for their daughter Anne, the doctor's godchild. Other goods and valuables, in the custody of a Mr. John Bigges at Stapleton, were bequeathed partly to Bigges himself and to his wife, partly to a Dr. Griphyth of the Court of Arches ${ }^{3}$ in settlement of their accounts, with the condonement of what was owing to Harding from an uncle of Griphyth's, a Dr. Geffrey." Finally, some

University on 31 July 1561 : 'Ioannes Martialis Anglas' (Lib. iv Intit., fo. 371); Wood, i. 250, 713 (bachelor of civil law, 1556) ; Dict. of Nat. Biogr.).

1 This William Smyth was entered in the list of members of the Louvain Univeraity on 30 April 1565 : 'M. Guilielmus Smyteus Anglus, pauper' (Liber iv Intit., fo. 413). He is probably identical with the William Smith, a member of the household of Gardiner, mentioned in his will (Nichols and Bruce, Wills, p. 46).

- This legacy was to be taken from a sum of money which was owing in England to Harding by one Henry Breyton.

- Probsbly this Dr. Griphyth is identical with John Griffyth of All Souls College, Orford, dootor of civil law on 7 July 1562, who, according to Wood (i. 719), was 'Principal of New Inn and the Queen's Professor of Civil Law, which last office he enjoyed four years while he was Bachelor of that faculty'.

- This Dr. Geffrey is probably William Geffry, doctor of lawa in July 1540, who after having been principal of St. Edward's and of Broadgates Hall, was appointed on 20 March 1553 chancellor of the church of Salisbury, of which Harding became treasurer in 1555, which may explain. the debt which was not settled yet at Geffry's death in 1558 ( Wood, i. 694). There was one John Gryffyth or Gruffyth, bachelor of civil law in July 1518, who was succeasively treasurer of Llandaff, dean of St. Aarph, and 
objects were given to the children of $\mathrm{N}$. Warner, who used to be Harding's farmer at 'Hinton Chappell vnto Crawley '.1 Part of some goods that had been deposited in the house of William Nicols, in Winchester, was left to Nicols himself, and the rest was divided between four of his old servants or their survivors. ${ }^{2}$

As to William Smyth, who had followed his master in his exile and had assisted him to the day of his desth, he received the rest of the goods in Bigges's care that had not been disposed of ; further all the remaining copies of The Confutacion of the Apologie, that he might turn them to the best advantage. Smyth, moreover, was released from a debt of 324 florins, which he owed for books, so that he must have acted as Harding's literary agent, and was probsbly one of the messengers who smuggled into England the polemical tracts of his master and of his friends. To the executor Thomas Hyde, Harding bequeathed his best gold ring, a gold portague, and an additional 5 pounds sterling; to his second executor, Thomas Bayley, his best gown with a gold portague.

These two friends carried out their charge with a scrupulous deference to his wishes. They ordered the burial and funeral services, the trigenaria and anniversaries in St. Gertrude's and in the Syon house; they paid the rent of Harding's rooms, the debt owing to Robert Payne, ${ }^{3}$ a priest, the wages of the English serving woman and of William Smyth, who, notwithstanding the ample legacy left to him, claimed the payment of several advances made during his master's illness. To put an end to his unceasing complaints the executors gave him, on the order of the rector, the sum of 20 florins. They further entered the money due from Thomas Dorman, "and claimed what was owing by Henry Covell and one Austin Legge. They superintended the sale of goods and books, and executed whatever was prescribed by the will as to gifts and legacies. When all had been cleared, they requested the rector and the deputies of the university to hear

a dignitary in the church of Salisbury, and who died in 1559 (Wood, i. 659). This John Gryffyth may have been Doctor Griffyth's uncle and Harding may have confueed the two.

1 Perhaps Crawley, near Winchester, where most of his possestions seem to have been. A Warner is mentioned amongst the household in Gardiner's will (Nicholas and Bruce, p. 46).

- Their namea are: John Scarlet, Robert Budd, Thomas Jonson, and John Simmeg.

2 'Robertas'Peyn Anglus' was matriculated in the Univenaity on 12 November 1563 (Lib. iv Intit., fo. 399).

- Thomas Dorman, formerly professor of civil law in Oxford, had migrated to the Netherlands in the beginning of Elizabeth's reign. Wood says that he settled at Antwerp. The absence of his name from the university matriculation register does not prove that he did not live in Louvain. At any rate he worked under the direction and on the suggestion of Thomas Harding and prote several books againot Jewel (Wood, i. 149, 272; Dict. of Nat. Biogr.). 
their account, for Harding as a member of the university was under their jurisdiction. As was the custom, the heirs and the creditors were summoned to a final meeting on 8 October 1573 in the name of Theodore Peelmans, the rector, by the university notary, Conrad Sylvius, and a notice to that effect was affixed to the doors of St. Peter's. On the appointed day the executors handed in a full statement of the assets, amounting to 1,766 florins, without the property in England. The expenses, about 1,627 florins in total, were detailed and justified. ${ }^{1}$ The account was approved and the executors were discharged from their responsibility, with the exception that a balance of about 139 florins had to be distributed in alms, according to the will of the deceased, amongst his poor and needy countrymen residing on this side the sea for the sake of their religion. As time went on, and English catholic life on the Continent began to concentrate at Douai, the memory of Harding was preserved in the old university only by his tombstone, in front of the altar of the Holy Trinity, in St. Gertrude's Church, adorned with the figure of a man propping with his right hand a tottering church, and, on the wall near the grave, an inscription on a brass plate, which was lost in the turmoil of the French revolution. ${ }^{2}$ H. DE VOCHT.

\section{The Bridgnorth Company of Smiths}

In the return made by the corporation of Bridgnorth to the commissioners on public records in 1833 the following paragraph appears : ${ }^{3}$

XIII. There are no ancient companies, guilds, or fraternities in this borough now existing: such companies formerly existed, but there are no records to be found applicable to the same.

In 1914 a volume was acquired by the British Museum ${ }^{4}$ (Add. MS. 38834, described in the catalogue as a guild-book), which gives details for the years 1595 to 1752 concerning one of these forgotten companies, the company of smiths, coopers, nailers, \&c. The occupations comprised under ' \&c.' make a long list : blacksmith, brazier, carpenter, cutler, fishhook-maker, freemason,

\footnotetext{
1 The assets were : sale of goods, 282 flor, 4 st.; sale of books, 184 flor. $2 \frac{1}{4}$ st.; gold, money, and debts, 1,300 flor. 4 st. ; tatal 1,766 flor. 9 st.; expenses and legacies, 1,627 flor. 7 st.

- This inscription was reproduced by John Pitt in his De Illustribus Angline Scriptoribus, and was copied about 1770 by Paquot, Fanti, p. 29.

3 App. to Report of the Commissioners on the Public Records (1837), p. 438.

- It bought from Mr. T. M. Blagg on 4 April 1914 and was once in the library of Mr. W. P. W. Phillimore. Fastened into the volume near the end is a small sheet of paper with notes relating to various members of the Bemand family.
} 